\title{
Correction: Quality of life and sexual functioning after vulvar reconstruction with the lotus petal flap
}

Hellinga J, te Grootenhuis NC, Werker PM, et al. Quality of life and sexual functioning after vulvar reconstruction with the lotus petal flap. Int J Gynecol Cancer 2018;28:1728-36. doi: 10.1136/ ijgc-2019-IGC.0000000000001340

In this paper, joint first authorship should have been listed for authors J. Hellinga and N.C. te Grootenhuis.

(C) IGCS and ESGO [2019]. No commercial re-use. See rights and permissions. Published by BMJ. Int J Gynecol Cancer 2019;29:1230. doi:10.1136/ijgc-2019-IGC.0000000000001340corr1

A) Check for updates 